\title{
Erratum to: Overexpression of the gibberellin 20-oxidase gene from Torenia fournieri resulted in modified trichome formation and terpenoid of metabolites Artemisia annua $\mathrm{L}$.
}

Phithak Inthima $^{1,2} \cdot$ Masaru Nakano $^{2} \cdot$ Masahiro Otani $^{2} \cdot$ Tomoya Niki $^{3}$.

Takaaki Nishijima $^{3} \cdot$ Masaji Koshioka $^{4} \cdot$ Kanyaratt Supaibulwatana $^{1}$

Published online: 18 July 2017

(C) Springer Science+Business Media B.V. 2017

Erratum to: Plant Cell Tiss Organ

Cult (2017) 129:223-236

DOI 10.1007/s11240-017-1171-1

There was a typing error in the title of the original publication. The title is correct in this erratum.

The online version of the original article can be found under doi:10.1007/s11240-017-1171-1.

Kanyaratt Supaibulwatana

kanyaratt.sup@mahidol.ac.th

1 Department of Biotechnology, Faculty of Science, Mahidol

University, 272 Rama VI Road, Ratchathewi District,

Bangkok 10400, Thailand

2 Faculty of Agriculture, Niigata University, 2-8050 Ikarashi, Niigata 950-2181, Japan

3 National Institute of Floricultural Science, 2-1 Fujimoto, Tsukuba 305-8519, Japan

4 College of Bioresource Sciences, Nihon University, 1866 Kameino, Fujisawa 252-0880, Japan 